\title{
Correction to: Triauxic growth of an oleaginous red yeast Rhodosporidium toruloides on waste 'extract' for enhanced and concomitant lipid and $\beta$-carotene production
}

\author{
Gunjan Singh ${ }^{1}$, Sweta Sinha ${ }^{1}$, K. K. Bandyopadhyay ${ }^{1}$, Mark Lawrence ${ }^{2}$, Ram Prasad ${ }^{3}$ and Debarati Paul ${ }^{1 *} \mathbb{C}$
}

\section{Correction to: Microb Cell Fact (2018) 17:182}

https://doi.org/10.1186/s12934-018-1026-4

After publication of the original article [1], the authors flagged that one of the co-authors' names was erroneously deleted during the review process and, as a result, the name is missing from the published article.

The missing co-author name is Dr. Ram Prasad, who should be listed as the fifth author. Please find the corrected author group published with this correction.
The original article can be found online at https://doi.org/10.1186/s1293 4-018-1026-4.

\section{Reference}

1. Singh G, Sinha S, Bandyopadhyay KK, Lawrence M, Prasad R, Paul D. Triauxic growth of an oleaginous red yeast Rhodosporidium toruloides on waste 'extract' for enhanced and concomitant lipid and $\beta$-carotene production. Microb Cell Fact. 2018;17:182. https://doi.org/10.1186/s1293 4-018-1026-4.

\section{Author details}

${ }^{1}$ Amity Institute of Biotechnology, Amity University, Sec 125, Noida, Uttar Pradesh 201313, India. ${ }^{2}$ Basic Sciences, College of Veterinary Medicine, Mississippi State University, Mississippi State, MS 39762, USA. ${ }^{3}$ School of Environmental Science and Engineering, Sun Yat-Sen University, Guangzhou 510006, China.

\section{Publisher's Note}

Springer Nature remains neutral with regard to jurisdictional claims in published maps and institutional affiliations.

Published online: 18 February 2019

\footnotetext{
${ }^{*}$ Correspondence: dpaul@amity.edu

1 Amity Institute of Biotechnology, Amity University, Sec 125, Noida, Uttar

Pradesh 201313, India

Full list of author information is available at the end of the article
} 